\title{
Reconciliation through language learning? A case study of the Turas Irish language project in East Belfast
}

David Mitchell $^{\mathrm{a}}$ and Megan Miller ${ }^{\mathrm{b}}$

\author{
${ }^{a}$ Irish School of Ecumenics, Trinity College Dublin at Belfast, UK \\ ${ }^{\mathrm{b}}$ Irish School of Ecumenics, Trinity College Dublin at Belfast, UK
}

\begin{abstract}
Language is frequently present in the conflictual symbolic politics of violent inter-group conflict. In Northern Ireland, the Irish language has long been contested and has been drawn into the maelstrom of cultural conflict since the 1998 Good Friday Agreement; hence the improbability of an Irish language learning/teaching initiative, operating since 2011, based in Protestant, pro-British East Belfast. This article offers the first academic analysis of the 'Turas' project, focusing on understanding its reconciliation contribution. Firstly, the article examines why language is so often contested in identity group competition. Secondly, findings of qualitative research inside Turas regarding the means and meanings associated with the project are reported. Thirdly, drawing on the case study, the article argues that language learning offers three distinct reconciliatory opportunities: revising destructive understandings of history; challenging exclusivist territorialisations of group memory; and facilitating critical reflection on self, and empathy for other.
\end{abstract}

ARTICLE HISTORY Ethnic and Racial Studies - received 10 July 2017; Accepted 28 November 2017

\section{KEY WORDS}

Northern Ireland, reconciliation, language, conflict, Turas, Irish language 
Collective and individual identity, dignity and power are bound up in the social stature of a group's 'mother tongue'. As Darquennes $(2015,16)$ writes: 'The degree of institutionalization and legitimization of a language mirrors its status and prestige in society, and is obviously also linked to the status, prestige, social power, and balance of the group that uses the language'. A group's perception that its vernacular is being sidelined by the state can raise deep existential anxieties and provoke intense reaction (Horowitz 2000, 219-224). At the same time, discovering and promoting cultural symbols that unite rather than divide is a potentially valuable part of building crossethnic social cohesion (Ross 2007; Schirch 2005). However, what language and language learning may offer in this regard has received little scholarly attention.

This article examines an unusual and unlikely grassroots peacebuilding project in East Belfast which uses language learning and cultural encounter as its principal vehicles. Language has not been a causal factor in the modern violent self-determination dispute in Northern Ireland. The two main identity groups, usually labelled Protestant (pro-British and 'unionist') and Catholic (pro-Irish and 'nationalist'), are not divided by an everyday language - all speak English. However, a history of colonialism and Anglicisation, and Irish nationalist cultural and political assertion, has given the Irish language a deep symbolic significance within the conflict (Goldenberg 2002). In the new Northern Ireland of cross-community power-sharing since 1998, the question of what official status or protection should be accorded the Irish language has become a 
bitterly contested issue, part of the identity politics and 'culture war' which have survived the end of violent communal competition (McMonagle and McDermott 2014).

Challenging this tendency towards cultural polarisation is the 'Turas' Irish language project, providing Irish language tuition, primarily to the local Protestant population, in unionist East Belfast since 2011. This article offers the first academic analysis of Turas. Three main questions are addressed. Firstly, how may the sociopolitical context of Turas be understood in terms of existing scholarship on the language-identity-conflict nexus? Secondly, what meanings do participants and leaders of the project ascribe to their involvement in Turas, and what do these reveal about the methods and processes through which Turas contributes to peace and reconciliation? Thirdly, what does this case study suggest about the general contributory potential of language learning to the amelioration of antagonism between groups in conflict? The article begins by investigating the connections between language and group identity conflict, and the meaning of reconciliation.

\section{Language, conflict and reconciliation}

The salience of language possession within groups' self-images may be observed in the manner in which language appears in the three dominant theoretical approaches to 
nationalism. In the primordialist view (more common among nationalists than scholars), a shared language, along with other base elements like religion, culture, physical characteristics, and a common homeland, are held up as authenticating the nation, demonstrating the group's shared experience and kinship through history (Geertz 1993, 259). In the modernist account, literacy, mass media and 'print capitalism' are pivotal to the emergence of the common awareness of time, space and destiny needed for the kind of collective consciousness demanded by nationalism, while the emerging bureaucratic state's requirement for standardised public education and communication consolidated homogenised linguistic, nationalist, blocs (see, for instance, Anderson 1991; May 2012). Meanwhile, in the 'ethno-symbolist' synthesis - which accepts nationalism as a modern phenomenon but contends that modern nations are based on pre-existing ethnic ties and cultures - language is part of a group's emotive 'myth-symbol complex' (a term associated with Armstrong 1982) in which 'linguistic symbols, especially, act as border guards delimiting the group boundary' (Smith 2015, 166).

Rarely has language difference caused violent conflict (Laitin 2000), yet contestation over language use has often been a symbolic facet of inter-group rivalries. For instance, the myth-symbol complex is the core of Kaufman's (2001) 'symbolic politics' theory of ethnic conflict, based on study of several post-Cold War conflicts in the Balkans and South Caucuses. In contrast to rationalist accounts which prioritise selfinterest as a motivator, Kaufman argues that, at the outbreak of ethnic violence, people 
mobilise in response to emotive group myths and symbols, likely evoked and manipulated by nationalist entrepreneurs. In the social psychology of nationalism, individual self-esteem is dependent on perceived relative group worth and, 'The existence, status, and security of the group thus come to be seen to depend on the status of group symbols, which is why people are willing to fight and die for them (Kaufman 2001, 25; see also Ross 2007; Horowitz 2000). Importantly, as Edwards (1985, 110) notes, the symbolic status of a language can exist even when it is not, or no longer, widely used in everyday communication.

Yet that communicative function does contribute to language's symbolic eminence - language is more than a unifying identity marker. Language facilitates the development of shared meaning and shared meaning makes interaction possible, a necessary condition for the formation of identity (Riley 2007, 33). To comprehend and be comprehended through language, then, permits the satisfaction of the elemental human desire for belonging: 'it is language, more than land and history, which provides the essential form of belonging, which is to be understood' (Ignatieff 1994, 7). Furthermore, as the medium through which religion, history, art, and everyday communication take form, language is ripe for nationalist construction as carrier of the essence of the collective, the repository of group memory, wisdom and imagination (Hutchinson 2013, 81). And with language so fundamental to enabling group belonging, linguistic freedom may be a condition of human 'dignity'. Kymlicka (2001) highlights 
that the nationalism which emerged in late eighteenth century Europe emphasised equality and the sovereignty of 'the people', eschewing the elitism of dynastic monarchies. Hence, 'mass education and mass democracy conducted in the vernacular are concrete manifestations of this shift towards dignity-bestowing national identity' (218). To experience public life in one's own language is dignifying and fosters individuals' identification with both the state and fellow citizens.

Scholarly work in socio-linguistics and other fields has examined the role of language planning and policy in managing social conflicts with a linguistic dimension (Darquennes 2015; May 2012; Mac Giolla Chríost 2003). However, more relevant to the present study is the potential of language as a shared symbol within a process of societal reconciliation after conflict. Before pursuing this point, some clarity on what is meant by 'reconciliation' is necessary. Here, reconciliation is understood as the development of positive intergroup relations after violent conflict, and thus primarily concerned with psychological, relational, and identity change, rather than institution/state building (though these are interrelated) (Bar-Tal and Bennink 2004; Lederach 1997). However, the term is variously defined and the concept has faced criticisms: that it is too vague and/or impossible; that it is solely religious and/or culturally contained to societies with a Christian heritage; that it puts the blame for conflict on individual attitudes rather than structural conditions; that it suggests that conflict is pathological and resolvable when it is in fact inevitable and must be managed 
(see Little 2011; Ryan 2007, 82-93; Hermann 2004; Porter 2003). The correct balance of the requirements commonly associated with reconciliation (such as forgiveness, reparations, amnesty, truth recovery, apologies, trials) is also intensely controversial (Ramsbotham, Woodhouse and Miall 2016, 286-298).

But despite debates over connotations and methods, the ideal of reconciliation as 'the ultimate goal of conflict resolution' (Ramsbotham, Woodhouse and Miall 2016, 286) or 'a consequence of successful conflict resolution' (Kelman 2004, 112) is widely recognised by peace and conflict scholars. It also has had, and continues to have, wide currency in Northern Ireland, usually denoting the unfinished business of a peace process which has focussed (relatively successfully) on political and security reform but had an unclear impact on sectarian attitudes and the sectarian division of society. While politicians have, in general, been lukewarm on reconciliatory language and policies, reconciliation was a stated aspiration in the 1998 Agreement (Northern Ireland Office 1998, 1). In the Stormont House Agreement (Northern Ireland Office 2014), intended to deal with outstanding peace process issues, promoting reconciliation was noted as one of the guiding principles. Thus, the term is used in this article to refer to the goal and process of stabilising peace though undermining politico-cultural polarisation and fostering attitudinal change towards inclusion and respect for difference.

Given the symbolic importance of language to group identity, it may be expected that a shared language could offer a powerful unifying symbol capable of both 
expressing and encouraging reconciliation (Ross 2012, 7). Moreover, language learning may also have a humanising effect by offering insight into another group's history, culture and experience, and undermining the exclusivism of traditional myth-symbol complexes. The imaginative capacity to empathise has been placed at the heart of postconflict reconciliation (Halpern and Weinstein 2004) and also identified by educationalists as a potential outcome of language learning (Byram and Morgan 1994, 24-31). Byram and Morgan $(1994,177)$ argue that foreign language education may succeed in 'developing learners' grasp of otherness and their moral evaluation of their own and others' perspectives through cognitive and affective reciprocity... they have the possibility of understanding and judging from within the perspective of others and their worlds'. This is precisely the kind of perspective shift which may engender the identity change required for reconciliation: 'the removal of the negation of the other as a central component of one's own identity' (Kelman 2004, 119). The concluding section of the article builds upon these ideas in light of the research findings.

\section{Language and conflict in Ireland}

Although it has not been widely required for everyday communication since the midnineteenth century, Irish is closely associated with Irish national identity, being a 
marker, reproducer, and cherished aspect of that identity wrapped in a myth commonly believed - that it is and has been the exclusive preserve of Catholic 'natives'. Thus, the Irish language has formed a significant component of Irish nationalism's myth-symbol complex. It is taught in Catholic schools and communities in Northern Ireland, and support for and/or knowledge of the Irish language has been one of the most unambiguous indicators of membership of the Catholic and broadly Irish nationalist community. For many Protestants, this association with their political opponents has imbued the language with an alien and threatening meaning (Malcolm 2009; Mac Póilin 2000). However, as O’Reilly $(1998,50)$ highlights, 'as with any symbol, there is no fixed relationship between signifier and signified, between the Irish language and the ideas and concepts which it represents'. This section reviews, necessarily briefly, how Irish came to be synonymous with Irish national identity, and specifically Irish separatist republicanism in Northern Ireland, and the basis for the potential re-interpretation of this meaning.

Irish was the main spoken language on the island of Ireland from at least the sixth century until the seventeenth century. It is a close relative of Scots Gaelic owing to the waves of settlement between the north of Ireland and Scotland for centuries before the 'Plantation' of settlers in the 1600s (Williams 2002). English political control in Ireland - beginning in 1169 but expanding and evolving henceforth - entailed the deliberate promotion of English as the language of the public sphere, sophistication, and 
social advancement. This led to the willing adoption of the language by many Irish, while emigration and the Great Famine of the 1840s further decimated the native Irishspeaking population (Crowley 2005). That said, Irish was yet to be viewed as the exclusive property of Irish political nationalists and Catholics. Many of the seventeenth century Protestant settlers from Britain spoke Scots Gaelic, while in the late eighteenth and early nineteenth centuries, Presbyterians in Belfast formed a number of learned societies and periodicals promoting the Irish language and Gaelic culture. Presbyterian ministers learned Irish as part of their training, as so many of their congregants spoke Irish (Blaney 1996).

In the late nineteenth century, as moves towards Irish independence gathered pace (and Protestant unionists mobilised in opposition), Irish intellectuals sought to stem the attrition of Irish culture through what became known as the Gaelic Revival, part of the fashion for romantic nationalist awakening across Europe at that time (Hutchinson 2013). In 1893, Conradh na Gaelige (the Gaelic League) was established to promote the Irish language. One of its founders was Douglas Hyde, a Protestant. Hyde strove to ensure that the League remained a cultural and non-political organisation, but at the organisation's conference in 1915, a resolution was passed making Irish independence a core aim, thus overturning the apolitical nature of its constitution. Hyde resigned, bemoaning those who had 'interpreted my teaching into terms of bullets and swords' (quoted in Foster 1990, 476). Nevertheless, the Gaelic 
League contributed to an Irish nationalism that was 'Anglo-phobic and anti-Protestant, subscribing to a theory of the "Celtic Race" that denied the true Irishness of Irish Protestants and Ulster Unionists' (Foster 1990, 459).

Nearly all of the signatories of the 1916 Proclamation of the Irish Republic, delivered during the Easter Rising, were members of the Gaelic League, believing fervently in the interdependence of the Irish language and Irish national identity (Goldenberg 2002, 17). When Ireland was partitioned in 1920 and the south achieved independence, this decolonising ideology permeated the new state. Irish was designated the first official language, learning Irish at school was made compulsory, Irish was required for employment in the civil service, and public administration and road signs were bi-lingual (see Mac Giolla Chríost 2012a). However, in the new Protestantdominated, pro-British entity of Northern Ireland which remained in the United Kingdom when the Irish Free State was formed, the Irish language was identified with the supposedly subversive and disloyal Catholic minority community, and the 'foreign' southern state (Andrews 1997). It was given little official recognition or support, and was banned in the Stormont Parliament, from road signs, and from broadcasts. The language, however, survived among Catholics through teaching in Catholic Church-run schools, and voluntary associations (Mac Ionnrachtaigh 2013, 72-92).

Contemporary attitudes to Irish in Northern Ireland have been shaped to a considerable extent by the embrace of Irish by republicans in the Sinn Féin party and 
the Irish Republican Army (IRA), and in particular republican prisoners, during the 'Troubles' in the 1980s (see Zenker 2013; Mac Ionnrachtaigh 2013; Mac Giolla Chríost 2012b). Like the militants of 1916, republicans made revival of the Irish language and Gaelic culture an explicit part of their combined military and electoral strategy; the movement 'consciously modelled itself on Irish cultural nationalism at the end of the nineteenth century and the discourse of decolonisation' (Nic Craith 2003, 79). At the same time, Irish language learning by republican paramilitary prisoners deepened, in the unionist mind, the language's association with anti-state subversion.

The 1998 'Good Friday’ Agreement sought to restore political stability by instituting cross-community power-sharing. The Agreement also recognised the identity and political aspirations of unionists and nationalists as 'equally legitimate' and stated that their cultures should be treated with 'parity of esteem'. However, how this principle should be implemented in real disputes over cultural expression and the public display of symbols has been a relentless source of controversy in post-Agreement Northern Ireland (Mitchell 2015; Nic Craith 2003). Irish republicans seek to advance their political objective of Irish unity through the promotion of Irish symbols and culture and challenging representations of Britishness and the British state within Northern Ireland. Accordingly, unionists oppose the visibility of Irish symbols and language in the public sphere, viewing it as a new 'weapon' in the old republican war. In republican areas street signs are in Irish, Sinn Féin symbolically uses Irish in political communications 
and in the Assembly, and the prospect of an Irish Language Act to protect and promote the language has been subject of long-running political dispute, being blocked by unionists.

\section{The present study}

Such was the polarised context in which Turas began to operate. The project - whose name means ‘journey’ in Irish and Scots Gaelic - originated in 2011 when a crosscommunity group of women undertook a six-week Irish language course. The programme was initiated by Sara Cook, a community worker at the East Belfast Mission (EBM) - a social outreach of the Methodist Church - on the Newtownards Road. A further course was offered later in the year, attracting nearly thirty people of mostly a Protestant/unionist background. The following year, Foras na Gaelige, a cross-border government body that promotes Irish language development, began supporting a programme of Irish language work at EBM co-ordinated by Linda Ervine, one of the early participants. In addition to language classes, the project began to run workshops with community groups providing information about the historical links between Protestants and the Irish language, and the Irish 'all around us' in place names, phrases and linguistic structures derived from Irish. Targeted at audiences traditionally 
reluctant to engage with Irish, and with the aid of PowerPoint and other visuals, scholarly work was presented in an accessible and relevant format.

Turas now facilitates seven weekly language classes for more than 200 learners as well as hosting Irish language singing classes, set dancing classes, and large-scale cultural events. By 2017, approximately 8000 people had taken part in Turas events. Turas has hosted public conversations on issues of language and identity and organised trips for its learners to West Belfast and the Irish-speaking Gaeltacht areas of the west of Ireland. While Turas is the only known project of its kind - an Irish language development effort based in a unionist area that specifically aims to provide Irish education to learners from Protestant backgrounds - it is not the first attempt at promoting Irish on an inclusive cross-community basis. A notable forerunner was the now defunct Ultach Trust, an organisation established in 1989 and funded, in the main, by the British Government (Mac Póilin 2000; McCoy 1997). It attempted to make Irish accessible to people of all backgrounds, and carried out educational work regarding the history of Protestants and Irish. One of its staff, Dr. Gordon McCoy, an expert on Protestants' historic and contemporary engagement with Irish, now works for Turas.

The findings reported below are primarily based on nine in-depth, unstructured interviews (on this approach see Brewer 2000,66) with leaders and participants in Turas carried out by the second author in the summer of 2015. One of the interviews was with Linda Ervine who acted as primary gatekeeper; other interviewees (two female 
and six male, three Catholic and five Protestant) remain anonymous. Demographic information is given below where salient. Informed consent was secured and interviews were audio-recorded and transcribed verbatim. Interviewees were asked open-ended questions about their experience of Turas, reasons for participating, and their cultural and political identity. The usual limitations regarding the generalisability of research based on a small number of self-selecting participants apply, but the qualitative phenomenological approach used here allows for a rich exploration of a topic which for some was sensitive, nuanced, and deeply felt. A thematic analysis was conducted in which transcripts were read and re-read, codes identified and progressively refined, and a report produced comprising illustrative extracts embedded within an analytic narrative (Braun and Clarke 2006).

The analytical lens was not that of a 'before and after' evaluation of the project, nor a detailed study of identity (though these are both incorporated to an extent), but that of reconciliation. The interviews were analysed for suggestions of what were perceived to be the ingredients of the project's success as a vehicle of such change, and how Turas may be stabilising peace by contributing to better relationships and understanding across Northern Ireland's sectarian divide. It should be lastly be reported that Mitchell (from Belfast, but who grew up in the Irish Republic, learning Irish by requirement at school) has attended Turas events, while Miller, from the United States, was a participant in Turas for three years. Our contrasting experiences with Irish 
sparked and sustained our intellectual curiosity about the project's work and its distinct contribution to Northern Ireland's transition from conflict; hopefully our experiences inside the project have enriched the data gathered, and its interpretation.

\section{Findings and discussion}

Five main themes were identified in the interviews and are reported below in turn: the impact of learning Irish on identity; the significance of experiencing new people and places; the appeal of the atmosphere and ethos; the importance of Turas's leadership; and challenges and limitations faced by the project.

\section{The impact of learning Irish on identity}

Turas's focus on the Irish language, a cultural symbol which has become associated with one 'side' in the modern conflict but in fact has a more expansive heritage, invites participants into a broader consideration of how polarised conflict narratives, transmitted through generations, have (mis)shaped individuals' and communities' understanding of their pasts. Ervine described how Turas helps overturn unthinkinglyheld stereotypes: 
People have this idea of what the Irish language is, and it's something that the IRA speak, so you couldn't be saying anything good in it ... and when you say to them, 'this is a language full of blessings, it's a kind language', it's a whole different take on it for them. And when you give them ownership of it, you just change their whole perception of the language.

This interviewee describes how political and cultural division had meant that the Irish language had been 'off limits' to him, until now:

[Turas] just seemed such a radical departure from the way Northern Irish, not just politics, but just life, works. Growing up in a Protestant family, son of an Orangeman, the Irish language was always kind of off limits, so Turas feels like a proper, systematic attempt to break that stigma, and that's something I believe in.

As well as highlighting Protestants' history of speaking and preserving the language, a major element of Turas' educational work concerns the origins of place names in Northern Ireland, 95 per cent of which derive from Gaelic. Ervine comments: 'The whole thing with place names and surnames, all of a sudden people understand that it's part and parcel of who and what they are, and it's all around them'. In her talk entitled ‘Gaelic Place Names for Dummies', Ervine highlights how, since Gaelic place names usually describe features of the landscape, people without knowledge of Irish are cut off from a deeper connection with place. At the same time, she shows how many place 
names derive from Scots Gaelic, or are of Norman origins, thus demonstrating the diverse and complex history of the inhabitants of Northern Ireland. This participant described how revelatory was Turas's educational work:

It's people's faces when they see it...you should see a few of them, they're sort of [shocked look], 'didn't know that, didn't know that, didn't know that', you know, and they're getting educated...which is, I have to say, part of reconciliation in my opinion'.

The close links between Irish and Scots Gaelic, most of whose speakers in Scotland are Protestants and share a degree of cultural affinity with Ulster Protestants, is another key theme in the educational work of Turas.

Protestant participants, it should be noted, are simultaneously discovering a part of their own heritage and a part of the 'other's'; not abandoning their own identity but discovering a seam of 'Irishness' shared with their traditional opponents. This is important to emphasise since a peacebuilding approach which requires the discarding of a group identity may be unwise and unsustainable: 'Making space for multiple identities is likely to be more productive than simply promoting a new one and extinguishing an existing one' (Ross 2007, 319). This chimes with a core aspiration of the Good Friday Agreement that people would move away from the traditional identity binary and recognise the inter-relatedness of cultural traditions in Britain and Ireland; notably, the Agreement recognised the right to be 'British, Irish or both' (Northern Ireland Office 
1998, 2). One participant commented that Turas 'allowed me to own my Irish identity and merge it with my British identity, both of which are important to me'. Ulster Protestants, as settler people whose allegiance to Britain has historically been under threat from Irish nationalism, have long been associated with an insecure and embattled identity. As one interviewee described, Turas challenges this kind of insecurity by imparting a sense of rootedness in Ireland and connection to the people of Ireland and Britain:

I enjoy my Irishness...it ultimately made me a stronger person... and what's wrong with the unionist community, with this fixation on Britishness is...it makes you weak. They don't have as many roots to put down into the ground, and they're easily blown over, buy the words of a politician or somebody else.

\section{The significance of experiencing new people and places}

The project has also enabled the crossing of territorial barriers, helping undercut the sectarian geography of Belfast which persists, notwithstanding peace and political stability (Shirlow and Murtagh 2006). Ervine remarked: '[the participants] have gone to places they have never been before ... and found people to be welcoming and friendly. Going to Donegal, to the Gaeltacht, even for people who have travelled, quite educated people, it's all been a new experience.' A Protestant participant commented how 
remarkable it was for her to visit places associated with Irish republicanism: 'I was never in Londonderry in my life until [Turas] took me there ... to be honest I mean twenty or thirty years ago I'd have been crapping myself on the Falls Road' [the heart of nationalist West Belfast]. A Protestant man noted the humanising effect of encountering people in new areas and that it may challenge Catholic stereotypes of Protestants: 'They [people in Donegal] found out that we are not all waving flags and shouting "no surrender" [an Ulster Protestant slogan] down here... we're actually normal people'. Similarly, another commented: 'It opens up that link with Irish speakers who are not of the same religious persuasion as yourself. It's easy to hate people that you don't know. But once you get to know them, then it's tougher'.

Significantly, the research suggested that, for some Turas participants, Turas had normalised travel into areas associated with the other community and may have had a ripple effect. One interviewee commented: 'it's become normal to them [Catholic participants in Turas] and they look forward to coming here'. A Catholic participant corroborated this:

I never felt uncomfortable, not once. As I say, the people within the Turas project, within the whole Skainos centre, were more than friendly and more than welcoming. And that sort of gave me encouragement to come here because of where I was coming from and to try to encourage others from my background or from where I live to join the group. 


\section{The appeal of the atmosphere and ethos}

Aside from the activities themselves, the spirit of Turas appears to have been crucial to the project's appeal and vitality: respondents commented on the warm atmosphere of the classes and events, and the ease of conversation and relationship-building. 'I couldn't believe the fullness of the community, it was so welcoming', said one participant; 'I immediately felt a sense of belonging from the first evening', said another. The added dimensions of Irish music and dance, and excursions, enhance the ethos of enjoyment and increase opportunities for forming meaningful relationships, while also taking Irish out of the textbooks and political speeches and presenting it in a living community context. For this interviewee, the fun factor was essential: 'It's basically the fun you have with it. It's the craic in here. OK, you're learning a language, but...it's more the craic. And it is fun.' Turas also attempts to maximise its appeal and accessibility through provision of classes for all levels, at a range of times, and for families.

Moreover, unlike peacebuilding work which, perhaps artificially, downplays political backgrounds in favour of what is thought to be neutral and shared, the subject matter of Turas appears to naturally elicit honest discussion regarding cultural identity: 'I know there are people in there with a different political perceptive from me and I feel like at least talking about it with them. I know we are not going to fall out over it and 
we're both going to come back to our Irish class together'. One participant felt that the novelty of Protestants learning Irish, and the diversity of the class ('all these different people, different reasons, different backgrounds, different motivations') created a special atmosphere that did not pertain in other Irish classes.

Some of the light-hearted camaraderie may derive from the collective awareness of the unlikelihood of what is taking place: Protestants learning Irish. This awareness is evident, and encouraged, in a loosely-autobiographical comedy play written by Ervine entitled What the Focal? (the Irish word for 'word') about a Protestant woman who begins to learn the language, despite the protestations of her strongly unionist husband. The play, later filmed and screened in community contexts, capitalises on how Turas, and the challenge it mounts to embedded notions of 'us' and 'them', provides fertile ground for stereotype-based jokes, irony, and self-deprecation. At the same time, it is an astute attempt to undermine stigma, and encourage people to, like the characters in the play, revise their prejudices and take part.

\section{Leadership and location}

Another major factor in the project's success and visibility appears to have been the enthusiastic and energetic leadership of Linda Ervine and, undoubtedly, her personal narrative. She was part of the initial class in 2011. To her surprise, genealogical 
research had revealed that, according to the 1911 census - the last time data on Irish speakers was collected in the north of Ireland until 1991 - her husband's descendents had been self-identified Irish speakers living on the Lower Newtownards Road. This discovery prompted her to further research regarding Protestants and the Irish language which would become the basis of her later educational work.

Her passion for the language springs from a sense of grievance that the sectarian divisions in Northern Ireland denied her, and the whole of the Protestant community, access to a significant, and indeed as she describes it, beautiful, part of their heritage. Another striking aspect of Linda's background is the fact that her late brother-in-law was David Ervine, a paramilitary leader who became an influential and highly-respected figure in the peace process as leader of the Progressive Unionist Party (PUP). Her husband, Brian, was also a leader of the PUP. Such strong working-class unionist credentials, together with her family history, have undoubtedly contributed to the credibility and, indeed, novelty of the Irish classes.

One participant credited Linda with helping people to feel able to cross traditional boundaries: 'Because of her skills and her personality, she's bringing people in from maybe Catholic West Belfast who wouldn't maybe come in here, and they're coming to loyalist, Protestant East Belfast and they're coming back week after week. So it's helping to liberate us from living in one particular pocket of the city.' Acknowledging that leading Turas involves a degree of courage, another participant 
said: 'I think we need more Turases. I think we need more Lindas. I think we need more people and organisations that are prepared and willing to put their own heads above the parapet and do something that will benefit society more widely'. Ervine's leadership was recognised in 2015 when she received the annual award for civic leadership from the Northern Ireland Community Relations Council, the public body which funds and supports peace and reconciliation work.

Although it was not mentioned in the interviews, the physical location of Turas has likely underpinned the project's attractiveness and accessibility. Obviously, being based in a staunchly unionist area has made the Irish language accessible to people from a Protestant background who would never have had the opportunity of learning Irish at school and who would have felt uncomfortable travelling to a nationalist area to attend an Irish class. However, the presence of Turas in the EBM building is also salient. EBM is a respected faith-based community organisation, long-embedded in the locality, and in 2012 it opened a multi-million pound development known as Skainos, envisioned to be a shared community hub. For Catholics (and indeed middle-class Protestants) unaccustomed to being in conflict-scarred working-class Protestant areas, Skainos offers a welcoming venue, devoid of associations with previous decades of violence and division. 


\section{Challenges and limitations}

Despite the innovative work done by Turas, strong countervailing pressures remain, not least the resilience of traditional political uses and perceptions of the language. For instance, a number of respondents admitting to being fearful of revealing their newfound interest to family and friends:

I haven't told anyone in my family that I'm learning Irish, simply because I'm sort of afraid of how they would react... It's easy for me to say to others that there needs to be more [projects like Turas] but I myself am not completely open and forthcoming about it, because I'm afraid of what people's reactions would be... I'd like to think that one day I'll be brave enough to say to my brother, or whoever, I'm learning the Irish language.

Another said: 'There's a bit of risk to the whole thing. I live in a predominantly lower middle class housing estate. I would say ... 99 per cent of them are Protestant, unionist ... and I don't tell anybody I learn Irish'.

The reach of Turas does remain relatively small. One Catholic respondent saw the need for a more widespread transformation of attitudes: 'When we get droves coming from the local streets, then we've won ... because some people still see it as the language of the Provos [the IRA]'. Another interviewee noted the limitations of the work of Turas: 'I love Turas, but on its own, it won't change Northern Ireland for the better. There needs to be proper political leadership'. Meanwhile, some respondents 
worried that Turas was fighting against the tide of public, political controversy surrounding the language, and that exclusive notions about the language would be sustained by divisive political arguments about the use and status of Irish, thus counteracting the positive work of Turas: 'It doesn't help when political parties claim ownership of it, and by the same token, people who resist or mock the language'.

These limitations caution against overstating the significance or impact of Turas. Indeed, civil society peacebuilding in general has faced criticisms for having a meagre, and/or impossible to quantify, impact (see Paffenholz 2010, 396-398; Gawerc 2006). However, grassroots peacebuilding of any kind can only be a cultural and interpersonal complement to political negotiation and structural change; 'peacebuilding from below is not a panacea that avoids the complex challenges of conflict resolution and peacebuilding at all levels and dimensions of conflict' (Ramsbotham, Woodhouse and Miall 2016, 285). While Turas cannot, for instance, directly meet the primary political grievance of many Irish speakers - the lack of legislation protecting the Irish language it can impact favourably the climate of opinion in the Protestant community regarding such legislation, detoxifying the debate. The ripples of influence emanating from one project are of course difficult to evaluate, but we may extrapolate from the media attention garnered by Turas, the active outreach work of its personnel, and the authors' own sense of its wide recognition, that its impact does reach beyond its immediate 'user' constituency. 


\section{Conclusion}

Turas is not the first project in which contemporary Northern Protestants have taken an interest in learning Irish. However, the uniqueness of Turas is twofold. Firstly, it has succeeded at creating a sustainable community of learners in a working-class Protestant area - ably led with a vibrant ethos. Secondly, the development of Turas has coincided with the intense period of cultural conflict from the 2012 flag protests onwards (on these events see Nolan et al., 2014), and also, in 2016-17, with the pivotal political dispute over Irish language legislation. Both of these have arguably given Turas a resonance it may not otherwise have attained. In relation to the Irish language legislation question, Turas has occupied a complex and distinctive political space. Providing one of the few pro-Union, Protestant endorsements of an Irish Language Act, Linda Ervine has argued that unionists need not fear such legislation but should view it as being in line with (United Kingdom) protections given to Scots Gaelic and Welsh. To the extent that this has frustrated unionists, and pleased republicans who view Irish language promotion and reconciliation between cultural traditions as bringing a united Ireland closer, this position was a risky one to adopt. But it was also one that can contribute to removing the Irish language from Northern Ireland's binary identity politics. 
What does Turas suggest about the nature of language learning as a reconciliation vehicle, as distinct from other such vehicles, such as, say, sport, the arts, or inter-church activity? On the basis of existing research, some potential contributions were noted above which may now be expanded in the light of the case study.

Firstly, since language learning is naturally accompanied by encounter with the history of the language, it can open a space for the discovery of shared historical experiences, or revision of narrow or destructive understandings of history. The history of a language is necessarily a history of its speakers' collective experiences and the physical spaces they have inhabited and named. Therefore, language learning elicits reflection and discussion regarding cultural identity, scrutiny of the myth-symbol complexes which have sustained enmity, and understanding of the historical power processes which have elevated or downgraded the status of various languages and produced the distinctive geographical patterns of language use in the present. In this sense, Turas exhibits what Lederach (2005, 35-36) calls 'paradoxical curiosity':

Cycles of violence are often driven by tenacious requirements to reduce complex history into dualistic polarities that attempt to both describe and contain social reality in artificial ways ... [P] aradoxical curiosity ... approaches social realities with an abiding respect for complexity, a refusal to fall prey to the pressures of forced dualistic categories of truth. 
As Kelman $(2004,123)$ notes, the historical work of reconciliation need not require establishing a single objective truth, but rather acknowledging that different historical narratives reflect different historical experiences, and 'admitting the other's truth into one's narrative'. Such critical excavation of history through language may not necessarily be relevant or possible in other conflict zones. However, in many cases the languages of neighbouring peoples are interlinked and study of those languages' histories are likely to reveal themes of commonality - migrations, intermarriage, intermixing, shared or related cultural practices or understandings - which do contradict the polarised and dominant communal remembrances.

Secondly, the close connection of language and place means that language learning may have a unique power to reframe groups' strong identification with particular territories, an identification which is problematic in the context of rival claims of self-determination. Above, it was mentioned how Turas educates people on the Gaelic origins of place names in Northern Ireland. That region is for Ulster Protestants what has been called an 'ethnoscape', a tract of territory which is synonymous with group identity through its status as 'witness to the group's survival as a cultural community' (Smith 1999, 151). A similar concept linking identity and landscape is the 'lingua-scape': 'an interweave of place-names and the ethnic contextuality of locale' (Mac Giolla Chríost 2003, 111). Discovering that place names originated in a language associated with the 'other' challenges the exclusive manner in 
which memory has been territorialised; this impact has been examined previously by Nash (1999). The standard conception that territorial sovereignty is indivisible and absolute, linked to the fact that for groups in conflict, collective identity is literally embedded in the soil of a place, is at the heart of the intractability of many conflicts. For this reason reframing ethnoscapes presents a formidable challenge to reconciliation. Language learning may be one contribution towards this. Again, comparative research is required regarding the extent to which such revelations of complexity are pertinent in other conflict zones yet the possibility, if it exists at all, is significant.

Thirdly, language learning has the potential to develop empathy for the members of another linguistic community. This is not simply because language acquisition creates 'common ground'- the learner comes to share the same communicative ability as the speaker - like other contact-based peace work. More than this, learning a language opens a window into another linguistic community's inner world - revealing nuances of culture and ways of life which would otherwise remain impenetrable (Byram and Morgan 1994). At the same time, this likely stimulates greater critical self-awareness regarding one's own taken-for-granted collective culture and worldview - a vital corrective to the self-righteousness characteristic of group identities in situations of violent conflict, and a contribution to the 're-humanisation' of the other required in reconciliation (Halpern and Weinstein 2004). In the case of Turas, this should not be overstated since all Irish speakers also speak English. Yet Irish language and culture, as 
expressed through the media, literature, road signs, place names, and other settings, in the North and South of Ireland, is rendered accessible to Protestants - in an otherwise impossible manner - through their acquisition of a degree of Irish language competence.

\section{References}

Anderson, Benedict. 1991. Imagined Communities: Reflections on the Origin and Spread of Nationalism. London: Verso.

Andrews, Liam. 1997. "The very dogs in Belfast will bark in Irish: The Unionist Government and the Irish Language, 1921-43." In The Irish Language in Northern Ireland, edited by Aodán Mac Póilin, 49-94. Belfast: The Ultach Trust.

Armstrong, John.1982. Nations Before Nationalism. Chapel Hill: University of North Carolina Press.

Bar-Tal, Daniel and Gemma Bennink, 2004. "The nature of reconciliation as an outcome and as a process." In From Conflict Resolution to Reconciliation, edited by Yaacov Bar-Simon-Tov, 11-38. Oxford: Oxford University Press.

Blaney, Roger. 1996. Presbyterians and the Irish Language. Belfast: Ulster Historical Foundation/The Ultach Trust.

Braun, Virginia and Victoria Clarke. 2006. "Using thematic analysis in psychology." Qualitative Research in Psychology 3: 77-101.

Brewer, John. 2000. Ethnography. Maidenhead: Open University Press.

Byram, Michael and Carol Morgan. 1994. Teaching-and-Learning Language-andCulture. Clevedon: Multilingual Matters 
Crowley, Tony. 2005. Wars of Words: The Politics of Language in Ireland, 1537-2004. Oxford: Oxford University Press.

Darquennes, Jeroen. 2015. "Language conflict research: a state of the art." International Journal of the Sociology of Language 235: 7-32.

Edwards, John. 1985. Language, Society and Identity. Oxford: Basil Blackwell.

Foster, R.F. 1990. Modern Ireland: 1600-1972. London: Penguin.

Gawerc, Michelle. 2006. "Peace-building: Theoretical and Concrete Perspectives." Peace \& Change 31 (4): 435-478.

Geertz, Clifford. 1993. The Interpretation of Cultures: Selected Essays. London: Fontana.

Goldenberg, L. 2002. The Symbolic Significance of the Irish Language in the Northern Ireland Conflict. Dublin: The Columba Press.

Halpern, Jodi and Harvey Weinstein. 2004. "Rehumanizing the other: empathy and reconciliation.” Human Rights Quarterly 26 (3): 561-583.

Hermann, Tamar. 2004. "Reconciliation: Reflections on the Theoretical and Practical Utility of the Term." In From Conflict Resolution to Reconciliation, edited by Yaacov Bar-Simon-Tov, 39-60. Oxford: Oxford University Press.

Horowitz, Donald. 2000. Ethnic Groups in Conflict. Berkeley: University of California Press.

Hutchison, John. 2013. "Cultural nationalism." In The Oxford Handbook of the History of Nationalism, edited by John Breuilly, 75-96. Oxford: Oxford University Press.

Ignatieff, Michael. 1994. Blood and Belonging: Journeys into the New Nationalism. London: Penguin. 
Kaufman, Stuart. 2001. Modern Hatreds: The Symbolic Politics of Ethnic War. New York, Cornell University Press.

Kelman, Herbert. 2004. "Reconciliation as identity change." In From Conflict Resolution to Reconciliation, edited by Yaacov Bar-Simon-Tov, 111-24. Oxford: Oxford University Press.

Kymlicka, Will. 2001. Politics in the Vernacular: Nationalism, Multiculturalism and Citizenship. Oxford: Oxford University Press.

Laitin, David. 2000. "Language, conflict and violence: the straw that strengthens the camel's back." European Journal of Sociology 40 (1): 97-137.

Lederach, John Paul. 2005. The Moral Imagination: The Art and Soul of Building Peace. New York: Oxford University Press.

Lederach, John Paul. 1997. Building Peace: Sustainable Reconciliation in Divided Societies. Washington DC: United States Institute of Peace.

Little, Adrian. 2011. "Debating peace and conflict in Northern Ireland: towards a narrative approach." In Political Discourse and Conflict Resolution: Debating Peace in Northern Ireland, edited by Katy Hayward and Catherine O’Donnell, 209-223. Abingdon: Routledge.

McMonagle, Sarah and Philip McDermott. 2014. "Transitional politics and language rights in a multi-ethnic Northern Ireland: towards a true linguistic pluralism?" Ethnopolitics 13 (3): 245-266.

Mac Giolla Chríost, Diarmait. 2012a. "A question of national identity or minority rights? The changing status of the Irish language in Ireland since 1922." Nations and Nationalism 18 (3): 398-416. 
Mac Giolla Chríost, Diarmait. 2012b. Jailtacht: The Irish Language, Symbolic Power and Political Violence in Northern Ireland, 1972-2008. Cardiff: University of Wales Press.

Mac Giolla Chríost, Diarmait. 2003. Language, Identity and Conflict: A Comparative Study of Language in Ethnic Conflict in Europe and Eurasia. New York: Routledge.

Mac Ionnrachtaigh, Feargal. 2013. Language, Resistance and Revival: Republican Prisoners and the Irish Language in the North of Ireland. London: Pluto.

Mac Póilin, Aodán. 2000. “Taig talk." In Gaelic Identities, Aithne na nGael, edited by Gordon McCoy and Maolcholaim Scott, 88-95. Belfast: Institute of Irish Studies, Queen's University of Belfast.

McCoy, Gordon. 1997. "Protestant learners of Irish in Northern Ireland." In The Irish Language in Northern Ireland, edited by Aodán Mac Póilin, 131-170. Belfast: The Ultach Trust.

Malcolm, Ian. 2009. Towards Inclusion: Protestants and the Irish Language. Belfast: Blackstaff.

Mitchell, David. 2015. Politics and Peace in Northern Ireland: Political Parties and the Implementation of the 1998 Agreement. Manchester: Manchester University Press.

May, Stephen. 2012. Language and Minority Rights: Ethnicity, Nationalism and the Politics of Language. Second edition. Abingdon: Routledge.

Nash, Catherine. 1999. "Irish placenames: post-colonial locations." Transactions of the Institute of British Geographers 24: 457-480.

Nic Craith, Máiréad. 2003. Culture and Identity Politics in Northern Ireland. Basingstoke: Palgrave Macmillan.

Nolan, Paul, Dominic Bryan, Claire Dwyer, Katy Hayward, Katy Radford and Peter Shirlow. 2014. The Flag Dispute: Anatomy of a Protest. Belfast: Queen's University. 
Northern Ireland Office. 1998. Agreement reached in the multi-party negotiations. Accessed 6 October 2017. https://www.gov.uk/government/publications/the-belfastagreement.

Northern Ireland Office. 2014. Stormont House Agreement. Accessed 6 October 2017. https://www.gov.uk/government/publications/the-stormont-house-agreement.

O'Reilly, Camile. 1998. "The Irish language as symbol: visual representations of Irish in Northern Ireland." In Symbols in Northern Ireland, edited by Anthony D. Buckley, 43-62. Belfast: Institute of Irish Studies, Queen's University.

Paffenholz, Thania. 2010. "What civil society can contribute to peacebuilding." In Civil Society and Peacebuiling: A Critical Assessment, edited by Thania Paffenholz, 381 404. Boulder: Lynne Rienner.

Porter, Norman. 2003. Reconciliation in Northern Ireland: The Elusive Quest. Belfast: Blackstaff.

Ramsbotham, Oliver, Tom Woodhouse and Hugh Miall. 2016. Contemporary Conflict Resolution, Fourth Edition. Cambridge: Polity

Riley, Philip. 2007. Language, Culture and Identity. London: Continuum.

Ross, Marc Howard. 2012. "Cultural contestation and the symbolic landscape: politics by other means?" In Culture and Belonging in Divided Societies: Contestation and Symbolic Landscapes, edited by Marc Howard Ross, 1-24. Philadelphia: University of Pennsylvania Press.

Ross, Marc Howard. 2007. Cultural Contestation in Ethnic Conflict. Cambridge: Cambridge University Press.

Ryan, Stephen. 2007. The Transformation of Violent Intercommunal Conflict.

Aldershot: Ashgate. 
Schirch, Lisa. 2005. Ritual and Symbol in Peacebuilding: Bloomfield, CT: Kumarian.

Shirlow, Peter, and Brendan Murtagh. 2006. Belfast: Violence, Segregation and the City. London: Pluto.

Smith, Anthony D. 2015. "Nations before nationalism? Myth and symbolism in John Armstrong's perspective." Nations and Nationalism 21 (1): 165-170.

Smith, Anthony D. 1999. Myths and Memories of the Nation. Oxford: Oxford University Press.

Williams, Nicholas. 2002. "Language." in The Oxford Companion to Irish History, edited by S.J. Connolly, 315-316. Oxford: Oxford University Press.

Zenker, Olaf. 2013. Irish/ness Is All Around Us: Language Revivalism and the Culture of Ethnic Identity in Northern Ireland. Oxford: Berghahn. 